\title{
Fruit Diversity for Agrotourism Development in Rawa Bayu, Bayu Village, Songgon, Banyuwangi
}

\author{
Ardina Tanjungsari, Azzah Fauziyah Cholis*, Christien Yacobina Riung, Lutvita Erya Rokani \\ Department of Biology, Faculty of Mathematics and Natural Sciences, University of Brawijaya, Malang, Indonesia
}

\begin{abstract}
Rural area in around Rawa Bayu tourism object has numerous fruit trees species which is possible to be integrated in the development of nature based tourism in Rawa Bayu. The aims of the study were describing the diversity of fruit species, mapping geographic positions of fruits plants grows, and exploring the local perspective about fruit plants species in its relationship with agrotourism development. Research methods consisted of fruit plant species exploration in Rawa Bayu ecotourism and its surrounding area, mapping the coordinates geographic using GPS (Global Positioning System), and implementing semi structured interviews with local respondends. Exploration was done by visiting Rawa Bayu ecotourism and its surrounding area, especially local people's yard. The fruit plant species was observed morphologically. The geographic position of fruit plant species was mapped using GPS. Semi structured interviews were implemented to 20 respondents, they are consist of locall community, tourist and local tourist in Rawa Bayu. Data was analized descriptively. This research found about 13 fruit plant species grows in Rawa Bayu area. Fruit plant species were potential for rural tourism development program. The most common fruit plant species found were durian (Durio zibethinus), salacca (Salacca zalacca), banana (Musa sp.), guava (Syzygium aqueum), jackfruit (Artocarpus heterophyllus), jengkol (Archidendron pauciflorum), langsat (Lansium domesticum), clove (Syzigium aromaticum), mangosteen (Garcinia mangostana), and avocado (Persea americana). Residents around Rawa Bayu ecotourism wishes the region became fruit agrotourism area to improve the people's economy.
\end{abstract}

Keywords: agrotourism, Banyuwangi, fruit conservation, tourist attractions.

\section{INTRODUCTION}

Indonesia is one of the countries that having highest biodiversity in the world. About 30,000 plant species are mostly live in the forest. There are only 4,000 sites have been identified. One of the existing biodiversity is the fruit crop. Fruit crops in Indonesia, especially in the area of forests and forest communities, are still not widely used optimally in the tourist industry which are currently being developed rapidly [1].

Agrotourism is an alternative of sustainable tourism which is part of the attraction in the form of agricultural businesses. Agrotourism activities were aimed to broaden the knowledge, experience, leisure and knowledge of the agricultural world [2]. The number of fruit trees in the area around the forest or settlements is like the implementation of agrotourism potential.

This study aimed to describe the diversity of fruit species and their spatial distribution around the attraction of Bayu Romo and the corridor along the Village of Rawa Bayu. The study also aimed to map fruit crops periodivity in one year and determine the public perception related to

\footnotetext{
* Correspondence address:

Azzah Fauziyah Cholis

Email : azzahbio@gmail.com

Address : Jl. Veteran Malang, 65145 Malang.
}

the potential development of agro-tourism potential of the fruit in Rawa Bayu.

\section{MATERIALS AND METHODS \\ Study Site}

Rawa Bayu is located in PERHUTANI area, Sambungrejo, Bayu Village, Songgon, Banyuwangi. It is located at the height of about $800 \mathrm{~m}$ asl. Rawa bayu is a swamp with many beautiful plants and preserved forest area around. Rawa Bayu has various tourist attraction such as swamp, religious tourism, tourism of Blambangan history, and fruit tourism. The most favorite fruit is Songgon's durians, which favored by many tourists. Songgon's durians are distinctive durian with red flesh of fruit and good taste. Various interesting attractions can be developed optimally to be fruit agrotourism [3].

\section{Exploration of Fruit Plants in Rawa Bayu}

Exploration of fruit plant surveyed on some location around Rawa Bayu, besides yard and farm. First, we interviewed local people about the type of fruit plants around Rawa Bayu and the one that growing at the yard in Bayu Village. Semi structured interviews were implemented to 20 respondents which is consisted of local community, tourist and local manager of Rawa Bayu ecotourism. Then mapping of fruit plants made 
from the observed fruit plant species. The geographic position of fruit plant species was mapped using GPS (Global Positioning System).

\section{Mapping Distribution of Fruit Plants}

The mapping begins with input data of fruit plants based on the text. Based programs text used is in the format storage of txt or csv. It used to input data vector for samples coordinates location in the form of text. Distribution map of fruit plants was made with software Quantum GIS (Geographic Information System). Data of distribution derived from the data that has been input based on the text. Distribution of fruit plants is featured in Quantum GIS in the form of vector, thus when processed it will appear as points of distribution. The addition of information map also made to increase the map clarity. Sensing is used to add information distribution of fruits plants by using Google Layers plugins.

\section{RESULT AND DISCUSSION}

\section{Morphometric and Morphology Characteristic}

Rawa Bayu has a lot of diversity of fruit plants. There are 10 species of fruit plants that have high dominance index, i.e. Durio zibethinus, Salacca zalacca, Syzygium aqueum, Musa sp., Artocarpus heterophyllus, Garcinia mangostana, Archidendron pauciflorum, Persea americana, and Lansium domesticum. Fruit plant has diversity in morphometric and morphology characteristic measurement to each species. This study use 10 replications to measure each species [4]. One of the measurement that conducted on the species is leaves' length and width. The measurement of leaves size of each species was shown in Fig. 1.

The fruits that found most around Rawa Bayu are $D$. zibethinus with tree habitus, height of \pm 25 $\mathrm{m}$ and diameters $\pm 30 \mathrm{~cm}$. Width and lenght of the leaves $\pm 11 \mathrm{~cm}$ and $\pm 4 \mathrm{~cm}$. Durio zibethinus is a tree with tap root, woody stem and sympo-dial branching, single leaf, short stem, pinnate leaves, green colour in adaxial and brown colour in abaxial, ellipse shape, white flower, oval shape fruit, coated by sharp thorns outer (yellow) [5].

Salacca zalacca has short-stemmed palm habitus with height about $\pm 6 \mathrm{~m}$ and diameters $\pm 39 \mathrm{~cm}$. Width and lenght of the leaves $\pm 100 \mathrm{~cm}$ and $\pm 50 \mathrm{~cm}$. Stems has thorns. Midrib will be the poitn for flower and fruit to grow, fruit protection by thorns with triangular shape and brown colour skin. This plant is a monocot plant.

Syzygium aqueum is in the form of tree with height reached $\pm 20 \mathrm{~m}$ and diameters $\pm 17 \mathrm{~cm}$.
Width and lenght of the leaves $\pm 26 \mathrm{~cm}$ and \pm 4.5 $\mathrm{cm}$. Stems has thorns. Stems are woody and short segmented. Leaf consist of only a stalk and leaf. It has a true fruit.

Musa sp. is gigantic herbs with height $\pm 2.5 \mathrm{~m}$ and diameters $\pm 6 \mathrm{~cm}$. Width and lenght of the leaves are $\pm 95 \mathrm{~cm}$ and $\pm 50 \mathrm{~cm}$, consecutively. Stem consist of true and pseudo stem. The leaves of Musa sp. has a long elips leaf, wide and flat edges (easily tore). The fruit in the form of clumps.

Artocarpus heterophyllus is a tree with height $\pm 12 \mathrm{~m}$ and diameters $\pm 8 \mathrm{~cm}$. Width and lenght of the leaves $\pm 23 \mathrm{~cm}$ and $\pm 5.5 \mathrm{~cm}$, respectively. Tree of $A$. heterophyllus has a tap root and woody stem, have characteristic of single leaf, elips, and pinnate leaves. Flower is in the form of multiple flower. Fruit has a yellow colour and oval shape.

Garcinia mangostana has habitus of tree with height $\pm 10 \mathrm{~m}$ and diameters $\pm 17 \mathrm{~cm}$. Width and lenght of the leaves are $\pm 24.5 \mathrm{~cm}$ and $7.5 \mathrm{~cm}$, respectively. G. mangostana has a woody stem, rounded with simpodyal branching and brown stem colour, single crossed leaves, brown fruit colour, rounded fruit with brown colour, and four leaves crown with elips shape and yellow colour. Fruit has a delicious taste [6].

Archidendron pauciflorum like a tree. Tree height $\pm 10 \mathrm{~m}$. Diameters $\pm 34 \mathrm{~cm}$. Width and lenght of the leaves are $\pm 16.5 \mathrm{~cm}$ and $\pm 4.5 \mathrm{~cm}$, respectively. A. pauciflorum has a tap root, simpodyal branching, single pinnate leaves, fruit in the form of pods and flatten like a spiral. Fruit has a brown colour.

Syzigium aromaticum is height of $\pm 12 \mathrm{~m}$ tree with diameters reached $\pm 225.5 \mathrm{~cm}$. Width and lenght of the leaves are $\pm 9.7 \mathrm{~cm}$ and $\pm 3.5 \mathrm{~cm}$, respectively. It has a tap root and monopodyal branching, multiple elips leaves, green colour and complete leaves, fruit and flower are red.

Persea americana has tree height of $\pm 8 \mathrm{~m}$ and diameters $\pm 12 \mathrm{~cm}$. Width and lenght of the leaves are $\pm 23 \mathrm{~cm}$ and $\pm 4 \mathrm{~cm}$, respectively. It has a tap a root and woody stems, brown colour, single elliptic pinnate leves, and multiple flower with yellow colour. Fruit have green or brown colour and fruit has delicious taste and good for health [7].

Lansium domesticum has tree height of $\pm 7 \mathrm{~m}$ and diameters $\pm 14 \mathrm{~cm}$. The leaves is compund leaves with pinnate leaves. This plant is a dicotyledous plant. This plan has a woody stem, monopodyal brancing, the fruit has a brown colour. 

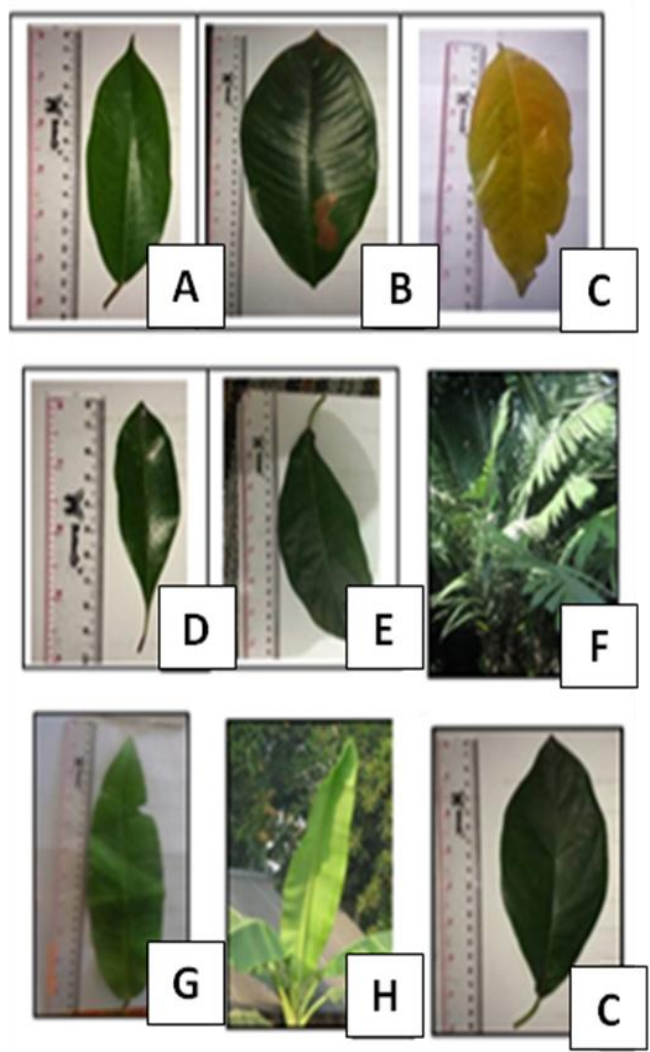

Figure 1. Leaves size: length and width

(A) D. zibethinus; (B) G. mangostana; (C) A. pauciflorum; (D) S. aromaticum; (E) P. americana; (F) S. zalacca; (G) S. aqueum; (H) Musa sp.; (I) A. heterophyllus.

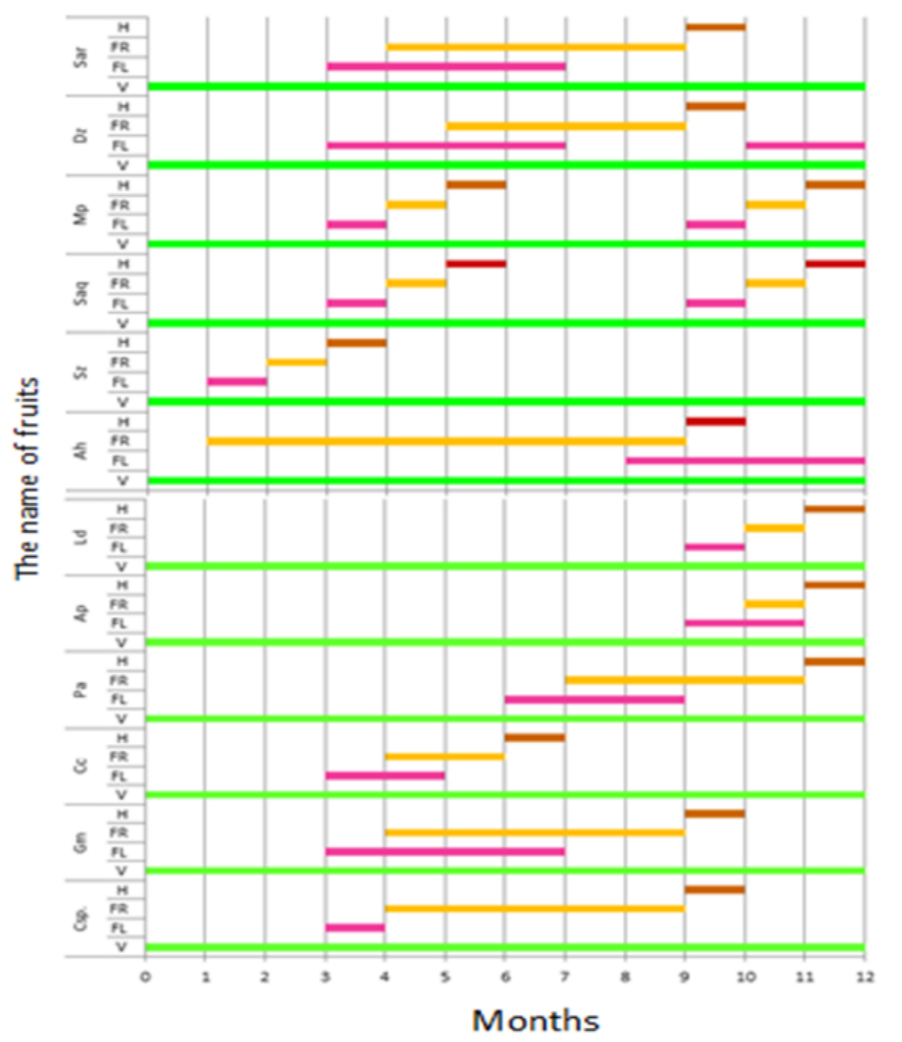

Description :

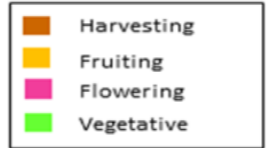

Sar: Syzigium aromaticum $\mathrm{Dz}$ : Durio zibethinus Mp : Musa paradisiaca Saq : Syzygium aqueum $\mathrm{Sz}$ : Salacca zalacca Ah : Artocarpus heterophyllus Ld : Lansium domesticum Ap : Archidendron pauciflorum $\mathrm{Pa}$ : Persea americana Cc : Chrysophyllum cainito $\mathrm{Gm}$ : Garcinia mangostana Csp : Coffea sp.

Figure 2. Fruit plants periodicity around RawaBayu 


\section{Public Knowledge about Fruit Crops}

Communities around Rawa Bayu grow fruit that has its own advantages and disadvantages. According to respondents, the community hopes that the fruit trees that abound surround the area of Rawa Bayu can be used as agrotourism fruit that will increase local people's income.

Total of $90 \%$ local people used pesticides to cultivate fruit trees. Pesticides that were often used are urea and ZA. Fertilization is an attempt to increase the fertility of the soil to fasten flowering and fruiting of plants. In addition, fertilization is done so that the compo-sition of soil nutrients remain in balance so it can grow and reproduce optimally [11]. The profit of growing fruit is it could be sold but local people sometimes suffer losses due to crop failure caused by pests. Society hopes that fruit crops in the area of Rawa Bayu more productive so that it can be used as agrotourism.

The whole community knows a lot of fruit trees around the Rawa Bayu ecotourism area. The reason local people grow's fruit as much as $60 \%$ for the economic interest that is sold to collectors. Tirtawinata and Fachruddin explained that ecotourism is a combination of agriculture and tourism [12]. Agrotourism can increase farmers' income from both farm and total farm households. Most fruit season is in July to October. Local people know the price of fruit on the market in accordance with the season. As much as $70 \%$ of the fruit crop is cultivated with treatment. Difficulties to grow fruit due to pests is as much as $60 \%$.
The existence of a wide variety of fruit around Rawa Bayu is one factor that can attract tourists. Based on interviews with visitors, it showed that travelers expect a collection of fruit crops in Rawa Bayu increased to be used as agrotourism fruits. Facilities and infrastructure should be improved so that more number of tourists will visit the area. The development of agriculture land into agro-tourism area will increase the tourist traffic which will contribute to an increase in the public opinion of tourist services [13].

About $70 \%$ of respondents knew of fruit trees around Rawa Bayu and $50 \%$ of respondents are interested in the fruit trees. Reasons of visitors attracted by the fruit crop are $20 \%$ as good, $10 \%$ liked, $10 \%$ is easy to get, and $10 \%$ because its free. Visitors on site purchase $50 \%$ of fruit around Rawa Bayu, because the fruit around Rawa Bayu tastes good $(80 \%)$. If the surrounding of Rawa Bayu developed into Agrotourism, then the loss is seasonal. Because, at any season of the fruit can be found. Expectations of future visitors to agrotourism in Rawa Bayu is $30 \%$ of the respondents answered more visitors, 30\% improved, and $20 \%$ more fruit trees.

\section{Map Distribution of Fruit Plants}

There are five kind of fruit which found around Rawa Bayu. After entering the gate, we found guava, banana, and durian. Other fruit can be found around Rawa Bayu (Fig. 3 and 4).

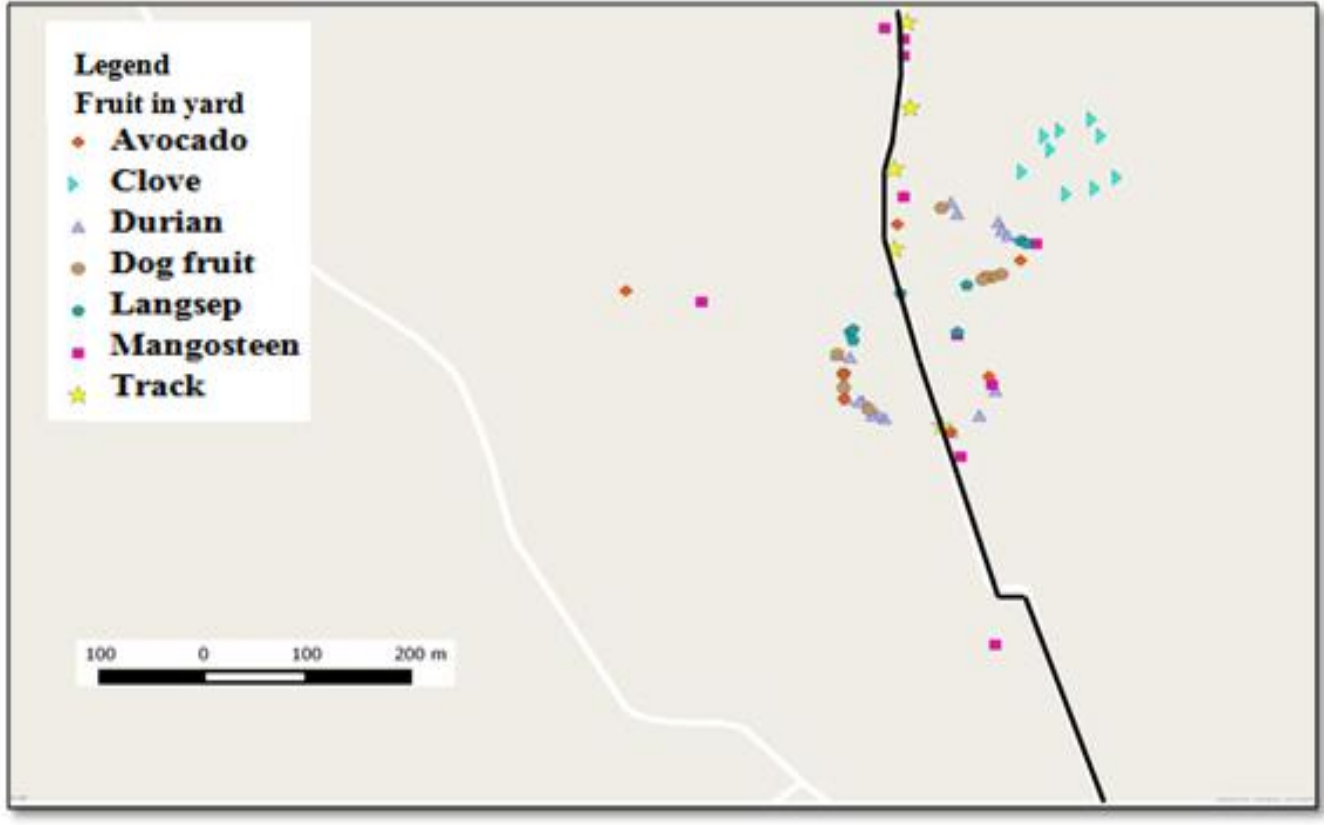

Figure 3. Distribution Map of Fruit Plants in the Yard 


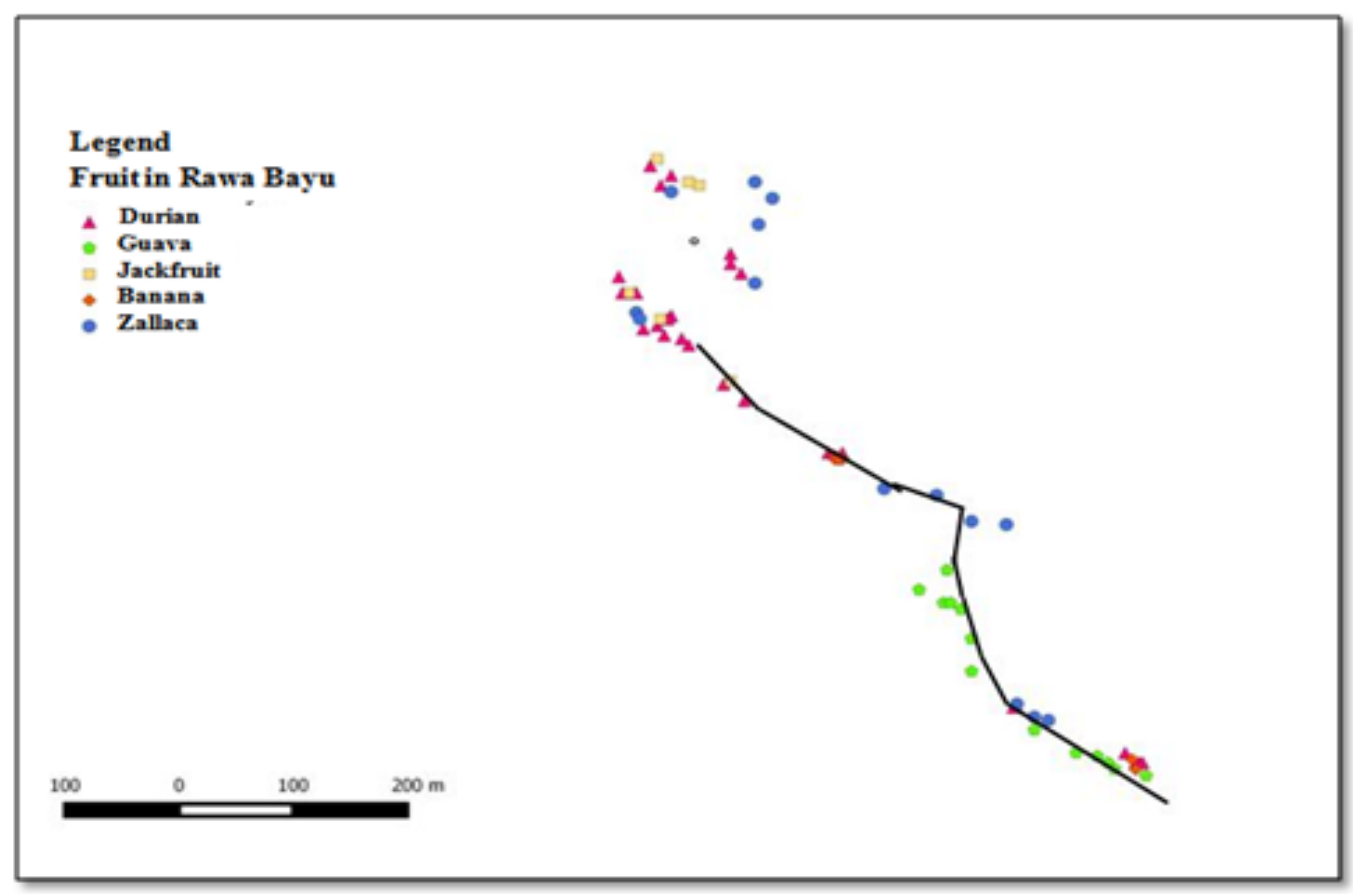

Figure 4. Distribution Map of Fruit Plants around Rawa Bayu

\section{CONCLUSION}

There are 13 fruit plants species which found around Rawa Bayu and there are 24 fruit plants species which found in the yard and farm. Total fruit plants found was 37 spesies, most fruits found were durian, zallaca, banana, guava, jackfruit, jengkol, clove, mangosteen, langsat, and avocado. Durian, zalacca, and jackfruit can be found around the swamp. There are banana, guava, and zallaca after entering gate. Along the way to the swamp there are guava, zallaca, and banana. Mangosteen, avocado, and langsep can be found around the residential area. Meanwhile, clove, jengkol, and durian can be found behind the house or local people's farm. The local people expect the region to be fruit agrotourism so it can increase their economy.

\section{REFERENCES}

[1] Anonim. 2007. Keanekaragaman jenis buahbuahan asli Indonesia dan potensinya. Research Center of Biology. Indonesian Institute of Sciences. Bogor.

[2] Fandeli, C. 2002. Perencanaan kepariwisataan alam 1 Ed. Faculty of Forestry. Gadjah Mada University. Yogyakarta.

[3] Adnyani, N. N. D., N. W. Sukerti and L. Masdarini. 2008. Strategi pengembangan agrowisata salak di Desa Sibetan, Kabupaten Karangasem. Ganesha University of Education. Singaraja.
[4] Yoeti, O. A. 2000. Ekosistem pariwisata berwawasan lingkungan. PT Pertja. Jakarta.

[5] Yuniarti. 2011. Inventarisasi dan karakterisasi morfologis tanaman Durian (Durio zibethinus Murr.) di Kabupaten Tanah Datar. Jurnal Plasma Nutfah, 1-6.

[6] Syatiaka, A. 2014. Karakterisasi tanaman Manggis (Garcinia mangostana L.) secara morfologis pada dua lokasi di wilayah Kabupaten Pesawaran. Lampung University. Bandar Lampung.

[7] Fazri, J. M. 2008. Identifikasi apokad (Persea Americana Mill.) dan kondisi budidayanya di Kabupaten Bogor, Jawa Barat. Bogor Agricultural University. Bogor.

[8] Zakiyah, S. Indriyani, and L. Hakim. 2013. Pemetaan sebaran dan karakter populasi tanaman buah di sepanjang koridor jalur wisata Desa Kemiren, Tamansuruh, dan Kampunganyar, Kabupaten Banyuwangi. Journal of Indonesian Tourism and Development Studies 1(2), 45-61.

[9] Megawati. 2010. Budi daya Cengkeh di Kabupaten Bantaeng dan Bulukumba, Sulawesi Selatan. Available at: http://www. worldagroforestry.org/.

[10] BAPPENAS. 2000. Durian (Durio sp.). Deputy Office Ministry of Research and Technlogy, Sector of Empowerment and Socialization of Science and Technology. Jakarta. 
[11] Rochani, S. 2007. Bercocok tanam Rambutan. Azka Press. Yogyakarta.

[12] Tirtawinata, M. R. and L. Fachruddin. 1999. Daya tarik dan pengelolaan agrowisata. Penebar Swadaya. Jakarta.

[13] Budiarti, T., Suwarto and I. Muflikhati. 2013. Pengembangan agrowisata berbasis masyarakat dan usaha tani terpadu guna meningkatkan kesejahteraan petani dan keberlanjutan sistem pertanian. Jurnal IImu Pengetahuan Indonesia 18 (3), 200-207. 